\title{
Protocol for \\ Evaluating the Impact of Social and Financial Education on Upper Primary School Children in Himachal Pradesh, India - A Cluster Randomized Trial
}

\author{
Vijay Avinandan ${ }^{1 *}$, Aman $_{\text {Kumar }^{1}, \text { Livia Remeijers }^{2} \text {, Dharmendra Chandurkar }}{ }^{1}$ \\ ${ }^{1}$ Sambodhi Research and Communications, C-126, Delhi-NCR, India \\ ${ }^{2}$ Aflatoun International, Overschiestraat 184, PO Box 15991, 1001 NL Amsterdam, The Netherlands
}

\begin{abstract}
Background: Imparting social and financial education to school-going students has garnered increasing policy attention by both developed and developing countries. Evidence from multiple countries shows that students who have undergone social and financial skill teaching are more likely to show prosocial behavior and financial prudence in life. While evaluation of social and financial teaching interventions for students across multiple countries has shown promising outcomes, very few studies examine the effect of such an intervention in the Indian context. Aflatoun International plans to implement its social and financial teaching program in public schools in the state of Himachal Pradesh in India. The evaluation aims to investigate the effect of the program on student social and financial behavioral outcomes.
\end{abstract}

Methods/Design: This present study is a cluster randomized trial to investigate the impact of an innovative social and financial skill teaching program for upper primary children aged between 9-16 years, across two districts in Himachal Pradesh, India. A total of 74 schools were randomly allocated to the treatment or control group. Outcomes to be measured are level of self-efficacy, knowledge of basic financial concepts, ability to solve simple financial tasks, level of patience and risk preference, amount of money saved, level of numerical ability, and knowledge on civil rights and responsibilities.

Discussion: The paper describes the protocol for evaluating an innovative social and financial teaching program for school-going students in Himachal Pradesh, India. The study has several potential implications. From a research perspective, the study is one of the first empirical investigations into the effect of the social and financial teaching program in public schools in India. From a policy perspective, the study will act as a proof of concept for the Government of Himachal Pradesh to scale the intervention. The evaluation is funded by Echidna Giving.

Trial registration: AEARCTR-0004870. Registered on 18 October 2019.

\footnotetext{
* Correspondence to Vijay Avinandan, Sambodhi Research and Communications, Delhi-NCR, India. Email: vijay.avinandan@sambodhi.co.in

Social Science Protocols, December 2019, 1-24. 1

http://dx.doi.org/10.7565/ssp.2019.2671
} 
Keywords: Life Skills; Financial Literacy; Education; Cluster Randomized Trial; Research Protocol.

\section{Background}

Cognitive skills are important determinants of many economic and social outcomes and are defined as a general mental capability involving reasoning, problem-solving, planning, abstract thinking, complex idea comprehension, and learning from experience (Gottfredson, 1997). At a macro level, cognitive skills are strongly related to a country's economic growth (Hanushek \& Woessmann, 2008). At a micro level, higher cognitive skills are associated with, among other things, increased health, better functioning of mental abilities in old age, and higher wages and better education (Heckman, Stixrud, \& Urzua, 2006; Heineck \& Anger, 2010). Social and financial skills are among the key cognitive competencies called for today in a job market characterized by fast job turnover, and the concomitant need for adaptability (Hirn, Thomas, \& Zoelch, 2018).

Social and financial skills education in India, termed as "soft skills" or "life skills," have received immense policy attention in recent years. The Draft National Education Policy 2019 (MHRD, 2019), soft skills education has been included as a part of instructional teaching in technical education for working youth (GOI). Related research in this context has generated largely mixed results, thereby calling for further research in imparting these skills to the targeted population. In this trial, we aim to evaluate classroom interventions targeted at improving the social and financial skills of children in north India.

Studies have found children using their social and cognition skills to win acceptance from peers and engage in social interaction from an early age (Menting, van Lier, \& Koot, 2011). As a result, their comprehension of people's inner states is enhanced, and they make further attempts to enact positive or prosocial behaviors (Denham et al., 2012), taking voluntary actions intended to benefit another, showing their associations with psychological well-being, social adjustment and school achievement (Conte, Grazzani, \& Pepe, 2018). However, recent literature analyzing the development of social skills among school students through targeted interventions has provided mixed results, thereby leaving this as an open area of research in the field. Studies have found that students studying in high-quality schools develop cognitive skills much faster than students attending low-quality schools (Borghans, Duckworth, Heckman, \& Weel, 2008). Umino and Dammeyer (2016) tested a non-instructional educational intervention focusing on children's prosocial experiences in Denmark. While this evaluation of the program showed that the intervention had positively improved the Danish children's quality of life and self-esteem, it showed mixed results in the context of Japanese school students, wherein students' knowledge of self, planning, and goal setting declined (Umino \& Dammeyer, 2018).

Financial literacy is an important skill for a younger generation due to several reasons, including the increasing likelihood of young people facing higher financial crisis, uncertain economic situations, which calls for prudent economic decisions. Financial literacy is particularly important for developing countries like India, where households have to survive on their savings and make optimal use of them for productive investments due to credit constraints (Rosenzweig \& Wolpin, 1993). Financial literacy would enable a household to make optimal use of scarce intra-household resources. Financial literacy has also been found to be correlated with

Social Science Protocols, December 2019, 1-24. 
more prudent financial decisions, use of formal savings, and insurance products (Xu \& Zia, 2012).

Financial literacy and skill are an active area of research in the field (Berková \& Krpálek, 2017). Psychology provides evidence that children in upper primary schools can understand basic economic concepts and managing their money and can thus be taught about personal finances (Otto, Schots, Westerman, \& Webley, 2006). It is, however, not clear if teaching these skills will lead to more prudent financial behavior. Frisancho (2018) found that school-based financial education programs for youth increased not only financial knowledge but also had positive impacts on self-control and consumption habits among students (Frisancho, 2018). However, as a potential downside of introducing children to the world of finance too early, children might prioritize income-generating activities at the expense of schooling. Grohmann et al. (2015) found that financial socialization through experience with work and money in adolescence has an unexpected negative effect on financial literacy on adulthood (Grohmann, Kouwenberg, \& Menkhoff, 2015).

In the present evaluation, we investigate the effect of an innovative social and financial skill teaching program aimed at increasing prosocial behaviors, financial literacy, and saving behavior using a Cluster Randomized Trial (CRT). The trial covers children in grades 6, 7, and 8, aged between 9-16 years, in public schools in Himachal Pradesh, India. The evaluation comprises of the two districts of Solan and Shimla. Results from the evaluation will have several implications. From a policy perspective, the evaluation will act as a proof of concept for the Government of Himachal Pradesh (GoHP) to implement the teaching program across all government public schools in the State. From a findings' perspective, the evaluation will explore whether the intervention has led to an increase in prosocial behaviors, financial literacy, and savings behavior among children.

The teaching program consists of two components, namely curriculum, and instruction. The curriculum is designed by Aflatoun International (AI). AI works towards strengthening social and financial skills among students through a network of partner organizations globally. MelJol in India implements AI's teaching curriculum. Facilitators from MelJol deliver the instruction in a classroom setting. The intervention to be tested starts at the beginning of the academic year and consists of weekly 60-minute sessions for 6-8 months. A facilitator's manual describes the teaching curriculum in detail for the program. The curriculum is divided into five components, spanning 31 sessions, each lasting an hour (see table 1), with Components 1 and 2 focusing on pro-social behaviors among children, articulated via self-understanding and exploration, and awareness on rights and responsibilities. While Components 3, 4, and 5 focus on financial literacy by teaching the concept of saving and spending, planning, and budgeting, and social and financial entrepreneurship.

The sessions are conducted as a part of extra-curricular activities during a school day. Participation in the sessions is voluntary, and in schools allocated for intervention, students in grades 6,7, and 8 are encouraged to participate in the teaching program. Participating students are grouped with 15-20 students per group, termed as an "Aflatoun group." No students are taken outside the classroom, and all students receive instruction from AI and MelJol trained facilitators. No intervention is provided to students in schools allocated to the control group.

Social Science Protocols, December 2019, 1-24.

http://dx.doi.org/10.7565/ssp.2019.2671 
Table 1. Session plan for the social and financial teaching program

\begin{tabular}{|c|c|c|}
\hline Sl. No. & Sessions & Curriculum Content \\
\hline 1 & Session 1 & Introduction to Aflatoun \\
\hline \multirow[t]{2}{*}{2} & Session 2 & Introduction to Mel and Jol \\
\hline & Component 1 & Self-understanding and Exploration \\
\hline 3 & Session 1.1 & Who am I? \\
\hline 4 & Session 1.2 & Who am I part 2 \\
\hline 5 & Session 1.3 & My relatives, my neighbors, and my friends \\
\hline 6 & Session 1.4 & My identity for self and others \\
\hline 7 & Session 1.5 & My identity for self \\
\hline 8 & Session 1.6 & Rainbow of emotions \\
\hline 9 & Session 1.7 & They help me \\
\hline 10 & Session 1.8 & Institutions around us \\
\hline \multirow[t]{2}{*}{11} & Session 1.9 & My village/my city/my district/my world \\
\hline & Component 2 & Rights and Responsibilities \\
\hline 12 & Session 2.1 & Our needs, our essentials, our luxuries \\
\hline 13 & Session 2.2 & Our rights \\
\hline 14 & Session 2.3 & Our Constitution \\
\hline 15 & Session 2.4 & An Aflatoun Club \\
\hline 16 & Session 2.5 & Setting up an Aflatoun Club \\
\hline 17 & Session 2.6 & Identifying the problem, finding the answer \\
\hline 18 & Session 2.7 & Some friends \\
\hline 19 & Session 2.8 & The shield of protection \\
\hline 20 & Session 2.9 & The right to health and the responsibilities \\
\hline 21 & Session 2.10 & Gender Equality for all \\
\hline \multirow[t]{2}{*}{22} & Session 2.11 & Celebrating Diversity \\
\hline & Component 3 & Saving and Spending \\
\hline 23 & Session 3.1 & Saving, investing, reusing \\
\hline 24 & Session 3.2 & Basic economic concepts \\
\hline 25 & Session 3.3 & Using resources well \\
\hline \multirow[t]{2}{*}{26} & Session 3.4 & Aflatoun Bank \\
\hline & Component 4 & Planning and Budgeting \\
\hline 27 & Session 4.1 & Planning of Money - Picnic for children \\
\hline 28 & Session 4.2 & Introducing planning and budgeting \\
\hline \multirow[t]{2}{*}{29} & Session 4.3 & Making a budget \\
\hline & Component 5 & Social and Financial Entrepreneurship \\
\hline 30 & Session 5.1 & Introducing entrepreneurship \\
\hline 31 & Session 5.2 & Further planning \\
\hline
\end{tabular}




\section{Methods}

\subsection{Aim and hypotheses}

The present study aims to examine the effect of AI's social and financial teaching program in Himachal Pradesh, India. The following study methodology will be reported following the Standard Protocol Items: Recommendations for Intervention Trials (SPIRIT) statement and guidelines (Chan et al., 2013) (see Figure 1).

\section{Primary research questions}

1. Does participation in life skills teaching program improve self-efficacy among students?

2. Does participation in life skills teaching program will improve financial literacy and savings behavior among students?

3. Does participation in life skills teaching program will improve patience and risk preference among students?

4. Does participation in life skills teaching program will improve numerical ability?

5. Does participation in life skills teaching program will increase student's knowledge of child rights and responsibilities?

\subsection{Trial Design}

This trial is registered in the AEA RCT Registry, and the unique identifying number is AEARCTR-0004870 (Avinandan, Kumar, Remeijers, \& Chandurkar, 2019). We apply a twoarm CRT design (see figure 2), which allows a robust evaluation of intervention outcomes relative to an equivalent control group. The unit of randomization is a public school.

Figure 1. SPIRIT recommended content for the schedule of enrolment, interventions, and assessments

\begin{tabular}{|c|c|c|c|c|c|c|c|c|c|}
\hline & \multicolumn{9}{|c|}{ STUDY PERIOD } \\
\hline \multirow[b]{2}{*}{ TIMEPOINT*** } & Enrolment & Allocation & \multicolumn{6}{|c|}{ Post-allocation } & \multirow{2}{*}{$\begin{array}{c}\text { Close-out } \\
t_{7}\end{array}$} \\
\hline & $-t_{1}$ & 0 & $t_{1}$ & $t_{2}$ & $t_{3}$ & $t_{4}$ & $t_{5}$ & $t_{6}$ & \\
\hline \multicolumn{10}{|l|}{ ENROLMENT: } \\
\hline Eligibility screen & $\mathrm{X}$ & & & & & & & & \\
\hline Informed consent & $\mathrm{X}$ & & & & & & & & \\
\hline Allocation & & $\mathrm{X}$ & & & & & & & \\
\hline \multirow{3}{*}{\multicolumn{10}{|c|}{$\begin{array}{r}\text { INTERVENTIONS: } \\
\text { Aflatoun curriculum } \\
\text { implemented by MelJol } \\
\text { ASSESSMENTS: }\end{array}$}} \\
\hline & & & & & & & & & \\
\hline & & & & & & & & & \\
\hline \multicolumn{10}{|l|}{ Pre-test } \\
\hline \multirow{3}{*}{$\begin{array}{r}\text { Knowledge of basic } \\
\text { financial concepts } \\
\text { Ability to solve simple } \\
\text { financial tasks on paper } \\
\text { Level of patience and risk } \\
\text { preference }\end{array}$} & & $\mathrm{X}$ & & & & & & & \\
\hline & & $\mathrm{X}$ & & & & & & & \\
\hline & & $\mathrm{X}$ & & & & & & & \\
\hline
\end{tabular}

Social Science Protocols, December 2019, 1-24.

http://dx.doi.org/10.7565/ssp.2019.2671 


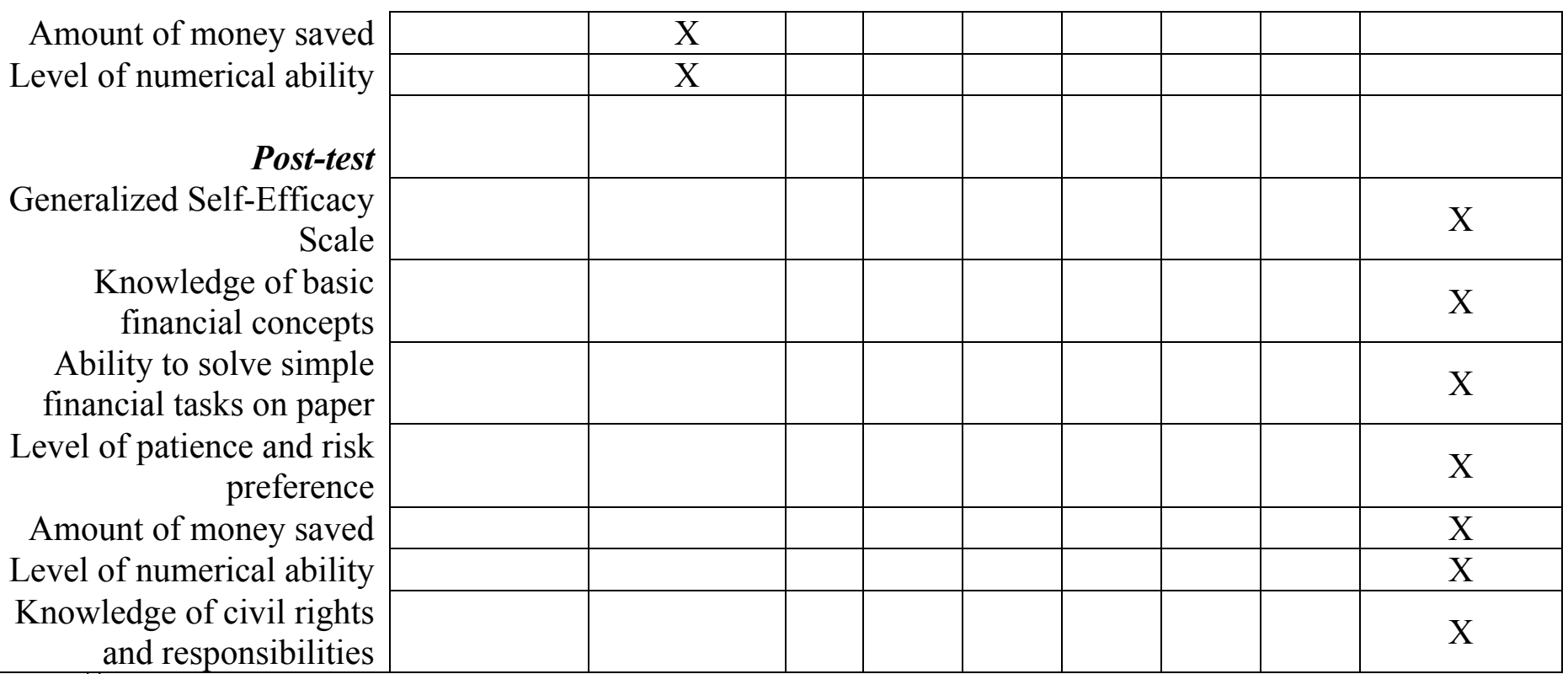

$t_{1=1 \text { st month } ;} t_{1=2 n d \text { month } ;} t_{3}=3 \mathrm{rd} \mathrm{month} ; t_{4}=4$ th month; $t_{5}=5$ th month; $t_{6}=6$ th month $; t_{7}=$ post-test.

\subsection{Randomization/treatment allocation}

Randomization is done by sourcing an initial list of 782 public schools in the study area with upper primary and upward divisions, and their characteristics from GoHP. An eligibility-criteria for CRT was established to shortlist schools from the list of 782 public schools. Based on the eligibility criteria, the schools should:

1. Not be covered previously under AI's training program;

2. Be co-educational;

3. Be government-owned and operated;

4. Have grades 6 to 8 ;

5. Have a minimum of 25 students across grade 6 to 8 ;

6. Have at least one full-time teacher;

7. Have at least one classroom in good condition;

8. Have at least one functional toilet for girls and boys or one common toilet;

9. Have functional electricity;

10. Have functional water;

11. Be located within 50 kilometers $(\mathrm{km})$ from the district headquarters.

A total of 161 schools were found to be satisfying the eligibility criteria. Out of the 161 schools, a random list of 74 schools (stratified by district and block) were invited to participate in the program. All the 74 schools agreed to participate in the trial, making it the final trial group. The 74 shortlisted schools were randomly allocated across treatment and control groups using statistical packages. The treatment group receiving the social and financial teaching program had 30 , and the control group receiving no intervention had 44 schools. The control group was oversampled by approximately $50 \%$ to achieve higher ex-ante power during the final analysis (Duflo, Glennerster, \& Kremer, 2007). The randomization was stratified by one level of geography and additional level(s) of indicators on school quality/strength collected from data

Social Science Protocols, December 2019, 1-24. 
available in the public domain. Schools were stratified in a manner where there are at least two schools in each strata cell, allowing us to randomize them either to the treatment or the control group. The final randomization had two levels of stratification interacting with each other, giving us four strata: (a) stratification by district (Shimla and Solan), and; (b) stratification by teacher strength (two groups, one each for above and below the median number of teachers in each district).

The randomization was tested for balance on 12 observable school characteristic namely: (1) number of classrooms in good condition; (2) number of other rooms in good conditions; (3) functional toilets for girls, boys and common ones; (4) presence of library; (5) number of students in each grade from 6 to 8; (6) distance from district headquarters; (7) number of male and female teachers; (8) classrooms and other rooms requiring major repairs; (9) construction material of boundary wall; (10) presence of playground; (11) number of blackboards, and (12) presence of separate room for headteacher. We find that in 1000 replications of the randomization process, we get statistical differences in observable characteristics, only $7.5 \%$ of the time, which is below the required cut-off of $10 \%$. Thus, indicating statistically robust randomization (Pocock, Assmann, Enos, \& Kasten, 2002).

\subsection{Participants}

The study will assess students across grades 6,7 and 8 in the trial group schools. A pre-test was conducted which comprised of 581 students in 30 treatment and 893 students in 44 control schools (roughly 20 students per school). Students in both schools across grades 6,7 , and 8 were picked randomly using the school attendance register. During the post-test, the same students will be re-assessed across treatment and control schools.

Data from the pre-test was used to test balance in various outcomes and survey questions conducted with randomly picked students across grades 6,7 , and 8 in all the 74 selected schools. The balance tests were done at both the school and student levels. At the school level, the balance tests were done using secondary data. At the student level, the selected students' response to 43 variables was tested. It was observed that none of the variables for school-level data, and none except two out of 43 variables for student-level data showed imbalance (see table 2 and 3). Putting the results together, we conclude that the randomization was successful and balanced on variables, increasing the trial's internal validity.

Social Science Protocols, December 2019, 1-24.

http://dx.doi.org/10.7565/ssp.2019.2671 
Figure 2. Diagram showing the flow of participants through the trial

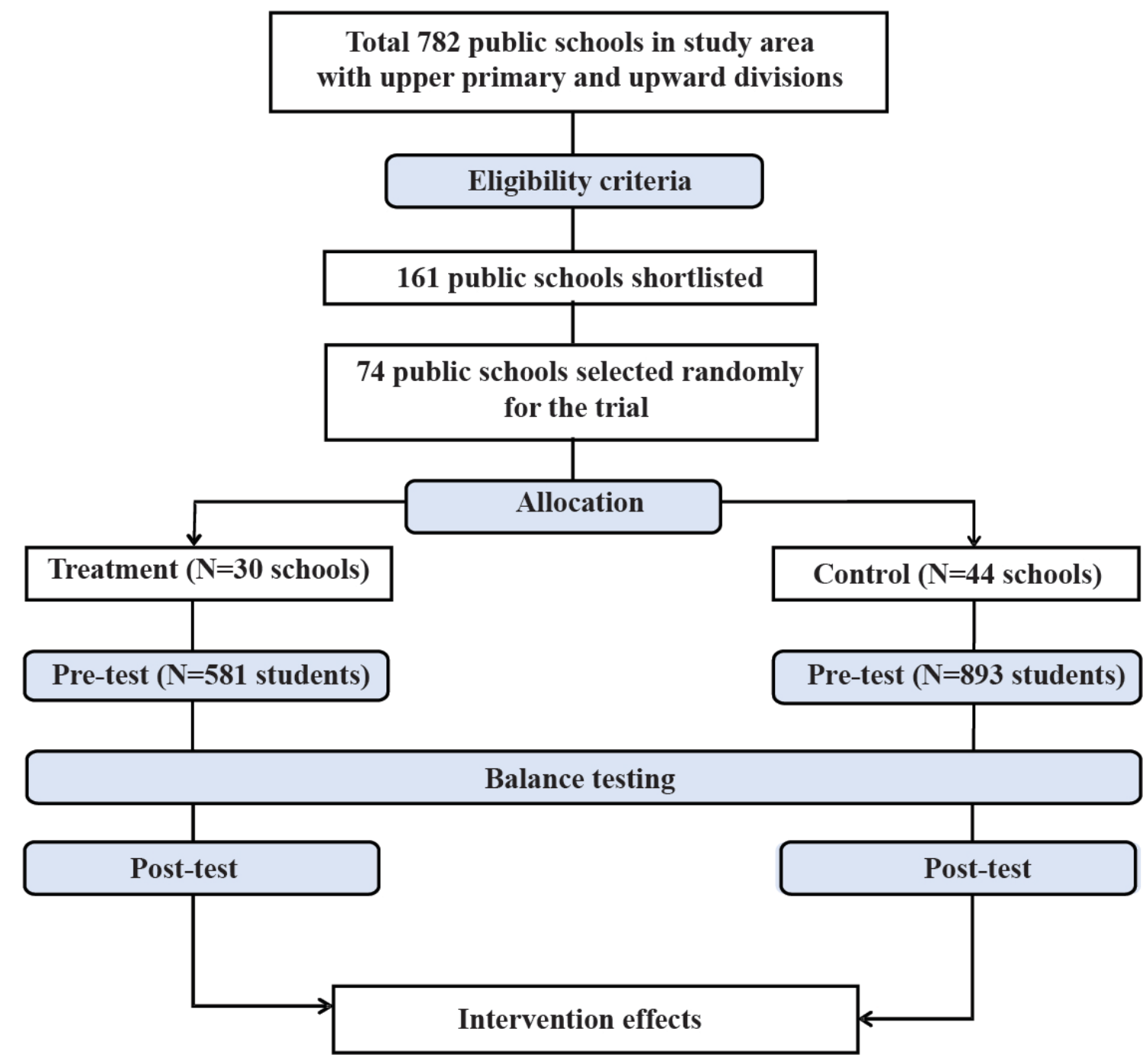

Table 2. Balance test for student-level outcomes

\begin{tabular}{|l|c|c|c|c|c|}
\hline \multicolumn{1}{|c|}{$\mathbf{1}$} & $\mathbf{2}$ & $\mathbf{3}$ & $\mathbf{4}$ & $\mathbf{5}$ & $\mathbf{6}$ \\
\hline \multicolumn{1}{|c|}{ Pretest Variable } & Observations & $\begin{array}{c}\text { Control } \\
\text { Mean }\end{array}$ & $\begin{array}{c}\text { Treatment } \\
\text { Mean }\end{array}$ & Coefficient & $\begin{array}{c}\text { Standard } \\
\text { Errors }\end{array}$ \\
\hline \multicolumn{7}{|c|}{ Basic Demographics } \\
\hline Student's Gender (Female =1) & 1474 & 0.428 & 0.437 & 0.009 & {$[.036]$} \\
\hline Age of Student & 1474 & 11.797 & 11.814 & 0.017 & {$[.085]$} \\
\hline Study Grade (6,7 or 8) & 1474 & 7.036 & 7.041 & 0.005 & {$[.034]$} \\
\hline Caste (General = 1, Others =0) & 1474 & 0.353 & 0.318 & -0.034 & {$[.047]$} \\
\hline Time taken to reach school & 1474 & 29.905 & 32.773 & 2.868 & {$[3.528]$} \\
\hline
\end{tabular}

Social Science Protocols, December 2019, 1-24.

http://dx.doi.org/10.7565/ssp.2019.2671 


\begin{tabular}{|c|c|c|c|c|c|}
\hline 1 & 2 & 3 & 4 & 5 & 6 \\
\hline Pretest Variable & Observations & $\begin{array}{c}\text { Control } \\
\text { Mean }\end{array}$ & $\begin{array}{l}\text { Treatment } \\
\text { Mean }\end{array}$ & Coefficient & $\begin{array}{c}\text { Standard } \\
\text { Errors }\end{array}$ \\
\hline \multicolumn{6}{|l|}{ (minutes) } \\
\hline $\begin{array}{l}\text { Anyone at home to help with } \\
\text { studies? }\end{array}$ & 1474 & 0.890 & 0.886 & -0.004 & {$[.024]$} \\
\hline $\begin{array}{l}\text { How many friends do you have } \\
\text { in school }\end{array}$ & 1474 & 3.197 & 3.012 & -0.185 & [.198] \\
\hline \multicolumn{6}{|c|}{ Awareness and Attitude } \\
\hline $\begin{array}{l}\text { Are you aware of the four main } \\
\text { rights of children? }\end{array}$ & 1474 & 0.075 & 0.071 & -0.004 & {$[.026]$} \\
\hline $\begin{array}{l}\text { Do you think child rights apply } \\
\text { equally to boys and girls? }\end{array}$ & 1264 & 0.799 & 0.756 & -0.043 & {$[.054]$} \\
\hline $\begin{array}{l}\text { Are you aware of your civic } \\
\text { responsibilities? }\end{array}$ & 1130 & 0.129 & 0.075 & -0.054 & {$[.027]^{*}$} \\
\hline $\begin{array}{l}\text { Are you aware of your } \\
\text { environmental duties? }\end{array}$ & 1363 & 0.761 & 0.742 & -0.019 & {$[.042]$} \\
\hline $\begin{array}{l}\text { I feel nervous when answering a } \\
\text { question in class }\end{array}$ & 1473 & 0.298 & 0.227 & -0.071 & {$[.044]$} \\
\hline $\begin{array}{l}\text { I would argue with a friend on } \\
\text { an issue that he/she has a } \\
\text { different opinion on an issue }\end{array}$ & 1372 & 0.576 & 0.627 & 0.051 & {$[.044]$} \\
\hline $\begin{array}{l}\text { If a person has a disability, it is } \\
\text { not acceptable to be their friend }\end{array}$ & 1443 & 0.494 & 0.476 & -0.018 & {$[.047]$} \\
\hline $\begin{array}{l}\text { If the person has HIV, it is not } \\
\text { acceptable to be their friends }\end{array}$ & 1028 & 0.387 & 0.379 & -0.008 & {$[.046]$} \\
\hline \multicolumn{6}{|c|}{ Savings and Budgeting } \\
\hline $\begin{array}{l}\text { Do you have any money saved } \\
\text { right now? }\end{array}$ & 1474 & 0.712 & 0.714 & 0.002 & {$[.04]$} \\
\hline $\begin{array}{l}\text { How much money have you } \\
\text { saved in total? }\end{array}$ & 1051 & 547.140 & 427.140 & -120 & [85.092] \\
\hline $\begin{array}{l}\text { How much money did you save } \\
\text { last week? }\end{array}$ & 1051 & 41.222 & 32.807 & -8.414 & [7.359] \\
\hline $\begin{array}{l}\text { Do you have a savings bank } \\
\text { account? }\end{array}$ & 1474 & 0.636 & 0.556 & -0.08 & {$[.054]$} \\
\hline $\begin{array}{l}\text { How much money did you } \\
\text { spend on yourself in the last } \\
\text { seven days }\end{array}$ & 1474 & 37.082 & 33.609 & -3.472 & [3.094] \\
\hline $\begin{array}{l}\text { How much money did you get } \\
\text { in last seven days }\end{array}$ & 1474 & 68.623 & 60.425 & -8.197 & [7.001] \\
\hline $\begin{array}{l}\text { Do you make a budget of } \\
\text { expenses before spending it? }\end{array}$ & 1474 & 0.449 & 0.460 & 0.011 & {$[.042]$} \\
\hline $\begin{array}{l}\text { How often are you able to spend } \\
\text { according to the budget? }\end{array}$ & 662 & 1.612 & 1.687 & 0.075 & {$[.067]$} \\
\hline
\end{tabular}




\begin{tabular}{|c|c|c|c|c|c|}
\hline 1 & 2 & 3 & 4 & 5 & 6 \\
\hline Pretest Variable & Observations & $\begin{array}{c}\text { Control } \\
\text { Mean }\end{array}$ & $\begin{array}{l}\text { Treatment } \\
\text { Mean }\end{array}$ & Coefficient & $\begin{array}{c}\text { Standard } \\
\text { Errors }\end{array}$ \\
\hline \multicolumn{6}{|c|}{ Confidence } \\
\hline I am concerned about my future & 1459 & 0.655 & 0.656 & 0.002 & [.047] \\
\hline $\begin{array}{l}\text { I am not sure what opportunities } \\
\text { I will have in the future }\end{array}$ & 1347 & 0.620 & 0.587 & -0.034 & {$[.053]$} \\
\hline $\begin{array}{l}\text { I have a plan for what I want to } \\
\text { be when I grow up }\end{array}$ & 1460 & 0.971 & 0.972 & 0.002 & [.012] \\
\hline $\begin{array}{l}\text { Have you participated in any } \\
\text { classroom activity in past one } \\
\text { month? }\end{array}$ & 1474 & 0.265 & 0.253 & -0.012 & {$[.055]$} \\
\hline $\begin{array}{l}\text { When I do poorly in the exam, I } \\
\text { am confident that I will } \\
\text { successfully deal with it }\end{array}$ & 1442 & 0.894 & 0.878 & -0.016 & {$[.021]$} \\
\hline $\begin{array}{l}\text { I have more confidence in } \\
\text { myself than most students I } \\
\text { know }\end{array}$ & 1324 & 0.799 & 0.819 & 0.02 & {$[.031]$} \\
\hline $\begin{array}{l}\text { I lack some important } \\
\text { capabilities that may keep me } \\
\text { from being successful }\end{array}$ & 1278 & 0.394 & 0.373 & -0.02 & {$[.051]$} \\
\hline I think I am doing pretty well & 1457 & 0.977 & 0.993 & 0.016 & {$[.007]^{* *}$} \\
\hline $\begin{array}{l}\text { I am doing just as well as other } \\
\text { kids my age }\end{array}$ & 1459 & 0.847 & 0.875 & 0.029 & {$[.027]$} \\
\hline $\begin{array}{l}\text { Even when others want to quit, I } \\
\text { know that I can find ways to } \\
\text { solve the problem }\end{array}$ & 1367 & 0.761 & 0.803 & 0.042 & {$[.039]$} \\
\hline $\begin{array}{l}\text { I find it very hard to talk in front } \\
\text { of the class }\end{array}$ & 1473 & 0.265 & 0.222 & -0.043 & [.039] \\
\hline $\begin{array}{l}\text { Someone always has to tell me } \\
\text { what to do }\end{array}$ & 1469 & 0.358 & 0.352 & -0.006 & {$[.048]$} \\
\hline \multicolumn{6}{|c|}{ Time and Risk Preferences } \\
\hline Patience score (test 1) & 1474 & 6.259 & 6.108 & -0.15 & [.186] \\
\hline Patience score (test 2) & 1474 & 6.242 & 6.158 & -0.084 & {$[.164]$} \\
\hline $\begin{array}{l}\text { Difference in patience scores } \\
\text { (Test } 1 \text { - Test } 2 \text { ) }\end{array}$ & 1474 & 0.017 & -0.050 & -0.067 & [.14] \\
\hline Risk Preference score & 1474 & 5.384 & 5.181 & -0.203 & {$[.233]$} \\
\hline \multicolumn{6}{|c|}{ Attendance and ASER test level } \\
\hline $\begin{array}{l}\text { For how many days in the last } \\
\text { six months has student attended } \\
\text { school }\end{array}$ & 1461 & 85.180 & 83.609 & -1.571 & [3.831] \\
\hline $\begin{array}{l}\text { Is the student at subtraction } \\
\text { level? }\end{array}$ & 1474 & 0.806 & 0.823 & 0.016 & [.029] \\
\hline
\end{tabular}

Social Science Protocols, December 2019, 1-24. 


\begin{tabular}{|l|c|c|c|c|c|}
\hline \multicolumn{1}{|c|}{$\mathbf{1}$} & $\mathbf{2}$ & $\mathbf{3}$ & $\mathbf{4}$ & $\mathbf{5}$ & $\mathbf{6}$ \\
\hline Pretest Variable & Observations & $\begin{array}{c}\text { Control } \\
\text { Mean }\end{array}$ & $\begin{array}{c}\text { Treatment } \\
\text { Mean }\end{array}$ & Coefficient & $\begin{array}{c}\text { Standard } \\
\text { Errors }\end{array}$ \\
\hline Is the student at division level? & 1198 & 0.664 & 0.659 & -0.005 & {$[.039]$} \\
\hline $\begin{array}{l}\text { Identified the correct } \\
\text { denominations and correct total }\end{array}$ & 1474 & 0.889 & 0.867 & -0.022 & {$[.023]$} \\
\hline Note: $* P$-value $\leq 0.1, * * P$-value $\leq 0.05, * * * P$-value $\leq 0.01$ \\
\hline
\end{tabular}

Table 3. Balancing test for school-level outcomes

\begin{tabular}{|l|c|c|c|c|c|}
\hline \multicolumn{1}{|c|}{$\mathbf{1}$} & $\mathbf{2}$ & $\mathbf{3}$ & $\mathbf{4}$ & $\mathbf{5}$ & $\mathbf{6}$ \\
\hline Pretest Variable & Observations & $\begin{array}{c}\text { Control } \\
\text { Mean }\end{array}$ & $\begin{array}{c}\text { Treatment } \\
\text { Mean }\end{array}$ & Coefficient & $\begin{array}{c}\text { Standard } \\
\text { Errors }\end{array}$ \\
\hline $\begin{array}{l}\text { What is the type of School } \\
\text { Gender of Respondent } \\
\text { (Female = 1) }\end{array}$ & 74 & 3.30 & 3.30 & 0.005 & {$[.176]$} \\
\hline $\begin{array}{l}\text { Educational Qualification of } \\
\text { Respondent }\end{array}$ & 74 & 0.27 & 0.23 & -0.039 & {$[.104]$} \\
\hline $\begin{array}{l}\text { Is the respondent head } \\
\text { teacher? }\end{array}$ & 74 & 0.86 & 0.87 & 0.003 & {$[.082]$} \\
\hline Tenure at school (months) & 74 & 33.27 & 32.70 & -0.573 & {$[8.318]$} \\
\hline $\begin{array}{l}\text { Number of students in } \\
\text { school }\end{array}$ & 74 & 62.50 & 53.83 & -8.667 & {$[10.018]$} \\
\hline $\begin{array}{l}\text { Number of teachers in } \\
\text { school }\end{array}$ & 74 & 10.05 & 8.67 & -1.379 & {$[1.491]$} \\
\hline Number of classrooms & 74 & 3.57 & 3.33 & -0.235 & {$[.164]$} \\
\hline $\begin{array}{l}\text { Is there a library/ reading } \\
\text { corner in the school? }\end{array}$ & 74 & 0.86 & 0.90 & 0.036 & {$[.076]$} \\
\hline $\begin{array}{l}\text { Is there a separate toilet } \\
\text { facility for boys and girls? }\end{array}$ & 74 & 0.98 & 1.00 & 0.023 & {$[.023]$} \\
\hline $\begin{array}{l}\text { Does the classroom have } \\
\text { benches for students to sit? }\end{array}$ & 74 & 1.00 & 0.97 & -0.033 & {$[.033]$} \\
\hline Is the classroom clean? & 74 & 0.98 & 0.93 & -0.044 & {$[.051]$} \\
\hline Note: * P-value $\leq 0.1, * * P-v a l u e \leq 0.05, * * *$ & $P-v a l u e \leq 0.01$ & & \\
\hline
\end{tabular}

\subsection{Outcome measures}

The outcome measures for students in grade 6, 7, 8 are - level of self-efficacy, knowledge on basic financial concepts, ability to solve simple financial tasks on paper, level of patience and risk preference, amount of money saved, level of numerical ability and knowledge on civil rights and responsibilities (see table 4).

For the post-test, the Generalized Self-Efficacy Scale (GSE) developed by Schwarzer \& Jerusalem (1995) will be used to measure the level of self-efficacy among students (Schwarzer \& Social Science Protocols, December 2019, 1-24. http://dx.doi.org/10.7565/ssp.2019.2671 
Jerusalem, 1995). GSE consists of 10 items with a 4-point response scale. Responses to all ten items are summed with final score values ranging from 10 to 40: higher score indicates greater self-efficacy. Internal reliability for GSE is between 0.76 to 0.9 Cronbach's alpha.

Knowledge of financial concepts and the ability to solve simple financial tasks on paper will be measured using a quiz designed by Berry, Karlan \& Pradhan (2018) for evaluating similar programs (Berry, Karlan, \& Pradhan, 2018). Knowledge of financial concepts will test student awareness on terms such as loans, investment, and functions of a bank. Ability to solve financial tasks will test student's financial literacy using hypothetical "shop games" in which the child will be given a list of goods and prices and a certain amount of money, all of which must be spent on the available goods. There will be two "shop games," and for each game, the index will include an indicator of whether the child correctly allocated the money, the absolute value of the difference between child's allocation and correct allocation, and the number of seconds taken to respond.

Level of patience will be tested through "gift games" used by Andreoni et al. (2019), wherein students make a series of decisions in which they are asked to choose between a smaller amount of rewards on the day of the test at the end of the day ("at the end of the day TODAY"), and a larger amount of rewards on the week after the experiment ("in ONE WEEK"). The first option represents impatient behavior when the child chooses a smaller sooner (SS) choice, while the second option represents patience signified by choosing larger later (LL) choice (Andreoni et al., 2019). Similarly, risk preference will be tested through "gift games," wherein students will be asked to choose between a riskless and risky option for rewards (Alan \& Ertac, 2014). Both patience and risk preference levels are associated with financial literacy and life outcomes (Castillo, Ferraro, Jordan, \& Petrie, 2011; Mudzingiri, Mwamba, Keyser, Bara, \& Hubert, 2019). Both patience and risk preference tests were administered during the pre-test and saw a high rate of response and variation. Internal reliability for patience test stood at 0.84 and risk preference test at 0.9 Cronbach's alpha.

The post-test will include questions of whether the student makes spending plans every week, their frequency of saving, and the total amount of money saved. Their level of numerical ability will be measured using mathematical tests prescribed by the Annual Status of Education Report (ASER) for students in grades 6 to 8 in India. Students will be first asked to solve two subtraction problems correctly, followed by one division problem. If the student correctly solves the division problem, s/he will be considered as proficient (at division level). If not, the student will be considered as being on an average level (at subtraction level). If the student is unable to solve subtraction problems, s/he will be asked to identify double-digit numbers correctly (at double-digit reading level). Students incorrectly answering double-digit reading level will be asked to identify single digits correctly (at single-digit level), which is considered as having the low numerical ability. Internal reliability for ASER numerical tests stands between 0.92 and 0.94 Cronbach's alpha (Vagh, 2013).

Student's knowledge of civil rights and responsibilities will be measured by testing whether the student is aware of concepts such as child and civil rights and responsibilities. The post-test will also include questions on whether students feel the rights are applicable for all socioeconomic groups. All the tests will be administered using pen and paper by trained testers in a fixed order to all children.

Social Science Protocols, December 2019, 1-24.

http://dx.doi.org/10.7565/ssp.2019.2671 
Table 4. Outcome measures

\begin{tabular}{|c|c|c|c|}
\hline Measure & Description & Administration & Reliability \\
\hline $\begin{array}{l}\text { Generalized Self- } \\
\text { Efficacy Scale }\end{array}$ & $\begin{array}{c}\text { Ten items on self- } \\
\text { efficacy } \\
\text { (Schwarzer \& Jerusalem, } \\
1995)\end{array}$ & $\begin{array}{l}\text { Individual } \\
\text { assessment }\end{array}$ & $\begin{array}{c}\text { Cronbach's alpha } 0.76 \\
\text { to } 0.9\end{array}$ \\
\hline $\begin{array}{l}\text { Knowledge of basic } \\
\text { financial concepts }\end{array}$ & $\begin{array}{l}\text { Developed within the } \\
\text { program }\end{array}$ & $\begin{array}{c}\text { Individual } \\
\text { assessment }\end{array}$ & NA* \\
\hline $\begin{array}{l}\text { Ability to solve simple } \\
\text { financial tasks on paper }\end{array}$ & $\begin{array}{l}\text { Hypothetical "shop } \\
\text { games." } \\
\text { (Berry, Karlan, \& } \\
\text { Pradhan, 2018) }\end{array}$ & $\begin{array}{l}\text { Individual } \\
\text { assessment }\end{array}$ & NA \\
\hline $\begin{array}{l}\text { Level of patience and } \\
\text { risk preference }\end{array}$ & $\begin{array}{l}\text { "Gift games" giving } \\
\text { students scenarios to } \\
\text { choose from } \\
\text { (Andreoni et al., 2019) } \\
\text { (Alan \& Ertac, 2014) }\end{array}$ & $\begin{array}{l}\text { Individual } \\
\text { assessment }\end{array}$ & $\begin{array}{l}\text { Cronbach's alpha for } \\
\text { patience test } 0.84 \text {; } \\
\text { Cronbach's alpha for } \\
\text { risk preference test } 0.9\end{array}$ \\
\hline $\begin{array}{c}\text { Amount of money } \\
\text { saved }\end{array}$ & $\begin{array}{l}\text { Developed within the } \\
\text { program }\end{array}$ & $\begin{array}{l}\text { Individual } \\
\text { assessment }\end{array}$ & NA \\
\hline $\begin{array}{l}\text { Level of numerical } \\
\text { ability }\end{array}$ & $\begin{array}{c}\text { ASER test on numerical } \\
\text { ability } \\
\text { (S. Vagh, 2013) }\end{array}$ & $\begin{array}{l}\text { Individual } \\
\text { assessment }\end{array}$ & $\begin{array}{c}\text { Cronbach's alpha } 0.92 \\
\text { to } 0.94\end{array}$ \\
\hline $\begin{array}{l}\text { Knowledge of civil } \\
\text { rights and } \\
\text { responsibilities }\end{array}$ & $\begin{array}{l}\text { Developed within the } \\
\text { program }\end{array}$ & $\begin{array}{l}\text { Individual } \\
\text { assessment }\end{array}$ & NA \\
\hline
\end{tabular}

*Not applicable

\subsection{Sample size calculations}

The trial will aim to cover roughly 1480 students across 74 schools. No data with similar measures from the same group were available for the Indian context to calculate statistical power. Hence, we utilized data provided by Brunner et a. (2018), where the school intraclass correlations (ICC) for self-efficacy were 0.03 (Brunner, Keller, Wenger, Fischbach, \& Lüdtke, 2017). Based on the ICC, the sample size for the trial, with a statistical power on at least $80 \%$ and alpha $=0.05$, should be large enough to detect an effect size of 0.19 of standard deviation (see figure 3). Evidence review in India observe that an increase in measures of less than 0.1 standard deviation is typically considered as small effect, while an increase of more than 0.3 standard deviations is considered a large effect, and an increase of more than 0.5 standard deviations a very large effect (Banerjee, Cole, Duflo, \& Linden, 2007; Duflo, Hanna, \& Ryan, 2012).

Social Science Protocols, December 2019, 1-24. 
Figure 3. Effect size calculation for the trial

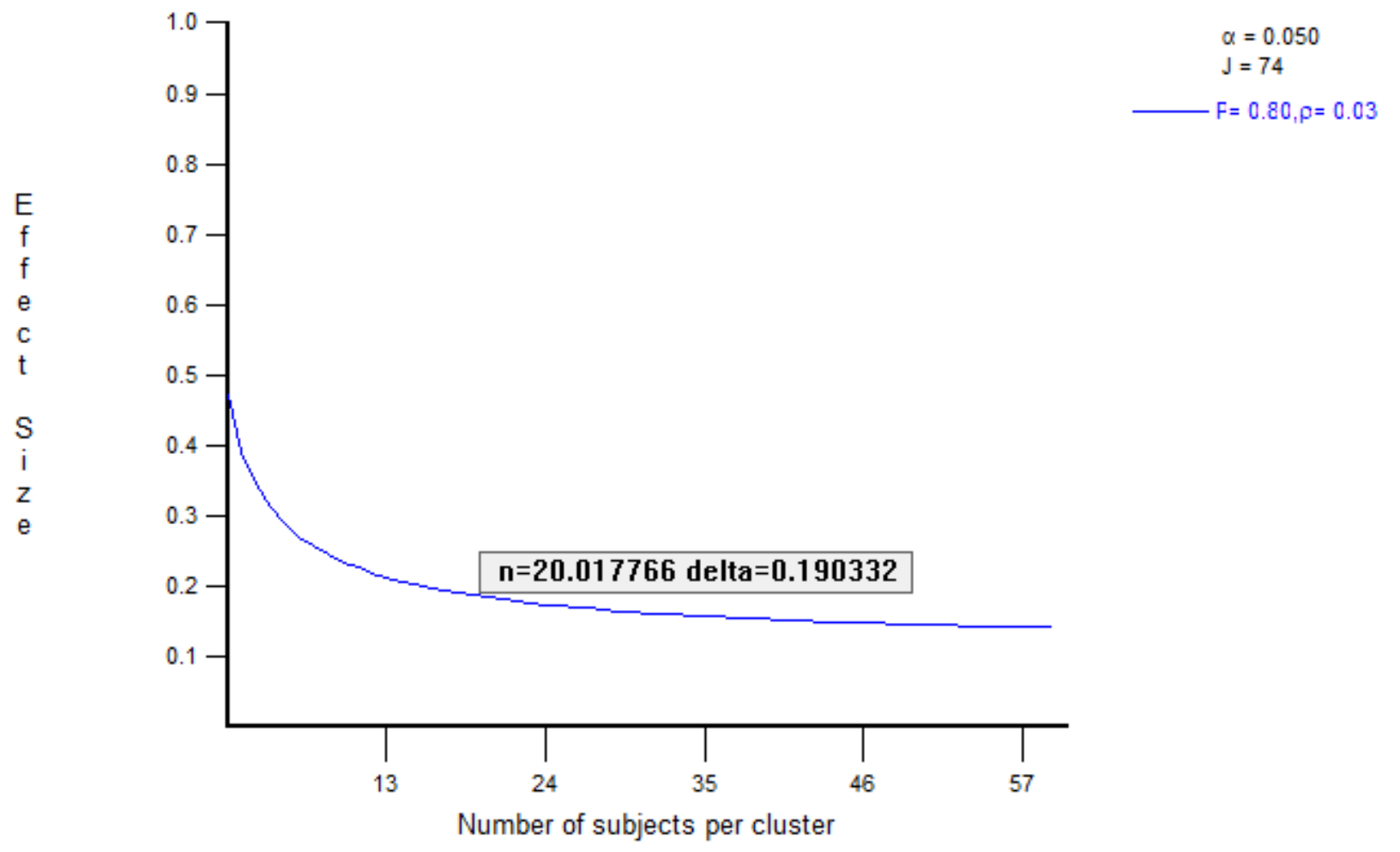

\subsection{Statistical analysis plan}

The effect of the program on outcome measures such as; self-efficacy, knowledge on basic financial concepts, ability to solve simple financial tasks, level of patience and risk preference, amount of money saved, level of numerical ability and knowledge on civil rights and responsibilities, will be assessed using regression models. Statistical analyses will be performed on the full sample collected during the trial. Also, effect sizes (Cohen's $d$ ) will be calculated to obtain an index of the improvement relative to the original performance mean and variation of the groups.

\subsection{Ethics approval}

The Public Healthcare Society (PHS), a third-party ethical oversight agency in India, has reviewed and approved the trial. All ethical guidelines mandated by PHS will be followed strictly through the trial. Informed consent of students, their parents/guardian, and class teachers will be required before participation in this trial, and their information will be kept confidential. Participants will be assigned random identification codes and will not be identified by their names or any other demographic detail. All information regarding the trial will be disclosed to participants and parents/guardians via informed consent before collecting data. Trained research investigators will procure the consent. The objective of this trial is to provide a proof of concept

Social Science Protocols, December 2019, 1-24.

http://dx.doi.org/10.7565/ssp.2019.2671 
for GoHP to implement the program across all public schools in HP. Students in the control school will also be a part of the teaching program at the end of the trial.

\section{Discussion}

The current trial aims to evaluate the effectiveness of an innovative social and financial skill teaching program on students in upper primary public schools. The intervention aims to extend social and financial teaching curriculum, which are intended to improve student's prosocial and financial behavior, to all public schools in Himachal Pradesh, India. More specifically, the trial will aim to confirm hypotheses whether the teaching program has improved self-efficacy, knowledge of basic financial concepts, ability to solve simple financial tasks, level of patience and risk preference, amount of money saved, level of numerical ability, and knowledge on civil rights and responsibilities among students. The study has several potential implications. From a research perspective, the study is one of the first empirical investigations into the effect of the social and financial teaching program in public schools in India. From a policy perspective, the study will act as a proof of concept for the GoHP to scale the intervention.

\section{Strengths and limitations}

Regarding the strengths of the trial, we use reliable measures to increase the consistency and repeatability of the results. Secondly, the trial has the potential to provide insights on the efficacy of social and financial teaching interventions, a relatively less explored area in the Indian context. This trial will be one of the first studies investigating a school-wide intervention that aims to improve prosocial and financial behaviors among students in public schools. Finally, results from balance tests find the randomization to be balanced, increasing the trial's internal validity.

Regarding the limitations, results from the trial may not be generalized to schools in other districts of Himachal Pradesh or other parts of the country. Secondly, the trial is limited to 74 schools, which reduces the effect size that can be detected at sufficient power. Finally, the posttest will be held immediately after completion of the classroom teaching sessions, which may lead to students giving better responses. The trial will be unable to comment on the retention of learnings among students.

\section{List of abbreviations}

$\begin{array}{ll}\text { CRT } & \text { Cluster Randomized Trial } \\ \text { GoHP } & \text { Government of Himachal Pradesh } \\ \text { AI } & \text { Aflatoun International } \\ \text { AEA } & \text { American Economic Association } \\ \text { km } & \text { Kilometers } \\ \text { GSE } & \text { Generalized Self-Efficacy Scale } \\ \text { ASER } & \text { Annual Status of Education Report } \\ \text { ICC } & \text { Intraclass Correlation } \\ \text { PHS } & \text { Public Healthcare Society }\end{array}$

Social Science Protocols, December 2019, 1-24. 


\section{Declarations}

Availability of data and materials: The datasets used and/or analyzed during the current trial are available from the corresponding author on reasonable request

Competing interests: The authors declare that they have no competing interests.

Funding: This trial is funded by Echidna Giving ${ }^{2}$. The funding body had no role in trial design, data collection, analysis, and interpretation of data.

Author contributions: VA and DC developed the study proposal and act as the principal investigators. AK contributed to the planning of data collection and recruitment. LR had a role in implementing the facilitator's manual for the program and coordination with implementing partners. VA, DC, and LR were the major contributors in writing the manuscript. All authors read and approved the final manuscript.

Acknowledgment: We are grateful to Government of Himachal Pradesh for providing approvals to implement the trial.

\section{References}

Alan, S., \& Ertac, S. (2014). Good things come to those who (are taught how to) wait: Results from a randomized educational intervention on time preference. Social Science Research Network. doi:10.2139/ssrn.2566405

Andreoni, J., Kuhn, M., List, J., Samek, A., Sokal, K., \& Sprenger, C. (2019). Toward an understanding of the development of time preferences: Evidence from field experiments. Journal of Public Economics, Elsevier, 177(C), 1-1. doi: 10.1016/j.jpubeco.2019.06.007

Avinandan, V., Kumar, A., Remeijers, L., \& Chandurkar, D. (2019). Evaluating the impact of social and financial education on upper primary school children in Himachal Pradesh, India A cluster randomized trial. The American Economic Association's Registry for Randomized Controlled Trials. Retrieved from https://www.socialscienceregistry.org/trials/4870

Banerjee, A., Cole, S., Duflo, E., \& Linden, L. (2007). Remedying education: Evidence from two randomized experiments in India. The Quarterly Journal of Economics, 122(3), 1235-1264. doi:10.1162/qjec.122.3.1235

Berková, K., \& Krpálek, P. (2017). Approaches to the development of cognitive process dimensions in financial literacy: an empirical study. Journal of International Studies, 10(3), 173-188. doi:10.14254/2071-8330.2017/10-3/13

Berry, J., Karlan, D., \& Pradhan, M. (2018). The impact of financial education for youth in Ghana. World Development, 102, 71-89. doi:10.1016/j.worlddev.2017.09.011

Borghans, L., Duckworth, A. L., Heckman, J. J., \& Weel, B. (2008). The economics and psychology of personality traits. Journal of Human Resources, 43(4), 972-1059. doi:10.1353/jhr.2008.0017

${ }^{2}$ https://echidnagiving.org/

Social Science Protocols, December 2019, 1-24.

http://dx.doi.org/10.7565/ssp.2019.2671 
Brunner, M., Keller, U., Wenger, M., Fischbach, A., \& Lüdtke, O. (2017). Between-school variation in students' achievement, motivation, affect, and learning strategies: Results from 81 countries for planning group-randomized trials in education. Journal of Research on Educational Effectiveness, 11(3), 452-478. doi:10.1080/19345747.2017.1375584

Castillo, M., Ferraro, P. J., Jordan, J. L., \& Petrie, R. (2011). The today and tomorrow of kids: Time preferences and educational outcomes of children. Journal of Public Economics, 95(1112), 1377-1385. doi:10.1016/j.jpubeco.2011.07.009

Chan, A., Tetzlaff, J., Atlman, D., Laupacis, A., Goetzsche, P., Krleza-Jeric, K., . . Moher, D. (2013). SPIRIT 2013 statement: Defining standard protocol items for clinical trials. Annals of Internal Medicine, 158, 200-207. doi:10.1016/j.jpubeco.2011.07.009

Conte, E., Grazzani, I., \& Pepe, A. (2018). Docial cognition, language, and prosocial behaviors: A multitrait mixed-methods study in early childhood. Early Education and Development, 29(6), 814-830. doi:10.1080/10409289.2018.1475820

Denham, S. A., Bassett, H. H., Way, E., Mincic, M., Zinsser, K., \& Graling, K. (2012). Preschoolers' emotion knowledge: self-regulatory foundations, and predictions of early school success. Cogn Emot, 26(4), 667-679. doi:10.1080/02699931.2011.602049

Duflo, E., Glennerster, R., \& Kremer, M. (2007). Using randomization in development economics reseach: A toolkit. Retrieved from https://economics.mit.edu/files/806

Duflo, E., Hanna, R., \& Ryan, S. P. (2012). Incentives work: Getting teachers to come to school. American Economic Review, 102(4), 1241-1278. doi:10.1257/aer.102.4.1241

Frisancho, V. (2018). The impact of school-based financial education on high school students and their teachers: Experimental evidence from peru. Inter-American Development Bank. Retrieved from https://publications.iadb.org/en/impact-school-based-financial-educationhigh-school-students-and-their-teachers-experimental

GOI (2015). Pradhan Mantri Kaushal Vikas Yojana. Ministry of Skill Development and Entrepreneurship, India. Retrieved from https://www.msde.gov.in/pmkvy.html

Gottfredson, L. S. (1997). Why g matters: The complexity of everyday life. Intelligence, 24, 79132.

Grohmann, A., Kouwenberg, R., \& Menkhoff, L. (2015). Childhood roots of financial literacy. Retrieved from https://www.diw.de/documents/publikationen/73/diw_01.c.513784.de/dp1504.pdf

Hanushek, E. A., \& Woessmann, L. (2008). The role of cognitive skills in economic development. Journal of Economic Literature, 46(3), 607-668. doi:10.1257/jel.46.3.607

Heckman, J. J., Stixrud, J., \& Urzua, S. (2006). The effects of cognitive and noncognitive abilities on labor market outcomes and social behavior. Journal of Labor Economics, 24. doi:10.1086/504455

Heineck, G., \& Anger, S. (2010). The returns to cognitive abilities and personality traits in Germany. Labour Economics, 17(3), 535-546. doi:10.1016/j.labeco.2009.06.001

Hirn, S. L., Thomas, J., \& Zoelch, C. (2018). The role of empathy in the development of social competence: a study of German school leavers. International Journal of Adolescence and Youth, 24(4), 395-407. doi:10.1080/02673843.2018.1548361

Menting, B., van Lier, P. A., \& Koot, H. M. (2011). Language skills, peer rejection, and the development of externalizing behavior from kindergarten to fourth grade. Journal of Child Psychology and Psychiatry, 52(1), 72-79. doi:10.1111/j.1469-7610.2010.02279.x

Social Science Protocols, December 2019, 1-24.

http://dx.doi.org/10.7565/ssp.2019.2671 
MHRD. (2019). National education policy. Government of India Retrieved from https://www.prsindia.org/sites/default/files/Draft_NEP 2019 EN Revised.pdf.

Mudzingiri, C., Mwamba, J. W. M., Keyser, J. N., Bara, A., \& Hubert, M. (2019). Indecisiveness on risk preference and time preference choices. Does financial literacy matter?. Cogent Psychology, 6(1), 1647817. doi:10.1080/23311908.2019.1647817

Otto, A. M. C., Schots, P. A. M., Westerman, J. A. J., \& Webley, P. (2006). Children's use of saving strategies: An experimental approach. Journal of Economic Psychology, 27(1), 57-72. doi:10.1016/j.joep.2005.06.013

Pocock, S. J., Assmann, S. E., Enos, L. E., \& Kasten, L. E. (2002). Subgroup analysis, covariate adjustment, and baseline comparisons in clinical trial reporting: current practice and problems. Statistics in Medicine, 21(19), 2917-2930. doi:10.1002/sim.1296

Rosenzweig, M. R., \& Wolpin, K. I. (1993). Credit market constraints, consumption smoothing, and the accumulation of durable production assets in low-income countries: Investments in bullocks in india. Journal of Political Economy, 101. doi:10.1086/261874

Schwarzer, R., \& Jerusalem, M. (1995). Generalized self-efficacy scale. In J. Weinman, S. Wright, \& M. Johnston (Eds.), Measures in health psychology: A user's portfolio. Causal and control beliefs (pp. 35-37). Windsor, UK: NFER-NELSON.

Umino, A., \& Dammeyer, J. (2018). Effects of a danish student-centered prosocial intervention program among Japanese children. Japanese Psychological Research, 60(2), 77-86. doi:10.1111/jpr.12183

Vagh, S. (2013). Validating the ASER testing tools: Comparisons with reading fluency measures and the read India measures. Retrieved from http://img.asercentre.org/docs/Aser\%20survey/Tools\%20validating_the_aser_testing_tools oct_2012_2.pdf

Vagh, S. B. (2012). Validating the ASER testing tools: Comparisons with reading fluency measures and the read India measures. Retrieved from

$\mathrm{Xu}, \mathrm{L} .$, \& Zia, B. (2012). Financial literacy around the world: An overview of the evidence with practical suggestions for the way forward. Retrieved from http://documents.worldbank.org/curated/en/264001468340889422/pdf/WPS6107.pdf

Social Science Protocols, December 2019, 1-24. 


\section{Appendix}

Reporting guidelines: SPIRIT 2013 checklist

\begin{tabular}{|c|c|c|}
\hline Section/item & $\begin{array}{l}\text { Item Description } \\
\text { No }\end{array}$ & $\begin{array}{l}\text { Addressed on } \\
\text { page number }\end{array}$ \\
\hline
\end{tabular}

Administrative information

Title 1 Descriptive title identifying the study design, population, interventions, and, if applicable, trial acronym

1

2a Trial identifier and registry name. If not yet registered, name of intended registry

Trial registration
2b All items from the World Health Organization Trial Registration Data Set

NA

Protocol version 3 Date and version identifier

Funding $\quad 4 \quad$ Sources and types of financial, material, and other support

Roles and

5a Names, affiliations, and roles of protocol contributors

responsibilities

5b Name and contact information for the trial sponsor

15

Role of study sponsor and funders, if any, in study design; collection, management, analysis, and interpretation of data;

5c writing of the report; and the decision to submit the report for publication, including whether they will have ultimate authority 15 over any of these activities

Composition, roles, and responsibilities of the coordinating

$5 \mathrm{~d}$ centre, steering committee, endpoint adjudication committee, data management team, and other individuals or groups overseeing the trial, if applicable (see Item 21a for data monitoring committee)

\section{Introduction}

Social Science Protocols, December 2019, 1-24. 


\begin{tabular}{lll}
\hline Section/item & $\begin{array}{l}\text { Item } \\
\text { No }\end{array}$ & Description \\
\hline $\begin{array}{l}\text { Background and } \\
\text { rationale }\end{array}$ & $6 \mathrm{a}$ & $\begin{array}{l}\text { Description of research question and justification for undertakin } \\
\text { the trial, including summary of relevant studies (published and } \\
\text { unpublished) examining benefits and harms for each intervention }\end{array}$ \\
& $6 \mathrm{~b}$ & $\begin{array}{l}\text { Explanation for choice of comparators } \\
\text { Objectives }\end{array}$ \\
7 & $\begin{array}{l}\text { Specific objectives or hypotheses } \\
\text { Trial design }\end{array}$ & $\begin{array}{l}\text { Description of trial design including type of trial (eg, parallel } \\
\text { group, crossover, factorial, single group), allocation ratio, and } \\
\text { framework (eg, superiority, equivalence, noninferiority, } \\
\text { exploratory) }\end{array}$
\end{tabular}

\section{Methods: Participants, interventions, and outcomes}

Study setting

Description of study settings (eg, community clinic, academic Eligibility criteria $10 \quad \begin{aligned} & \text { Inclusion and exclusion criteria for participants. If applicable } \\ & \text { eligibility criteria for study centres and individuals who will } \\ & \text { perform the interventions (eg, surgeons, psychotherapists) }\end{aligned}$ hospital) and list of countries where data will be collected. 3 Reference to where list of study sites can be obtained $2-4$

.




\begin{tabular}{llll}
\hline Section/item & $\begin{array}{l}\text { Item } \\
\text { No }\end{array}$ & Description & $\begin{array}{l}\text { Addressed on } \\
\text { page number }\end{array}$ \\
\hline Outcomes & 12 & $\begin{array}{l}\text { Primary, secondary, and other outcomes, including the specific } \\
\text { measurement variable (eg, systolic blood pressure), analysis } \\
\text { metric (eg, change from baseline, final value, time to event), } \\
\text { method of aggregation (eg, median, proportion), and time point } \\
\text { for each outcome. Explanation of the clinical relevance of chosen } \\
\text { efficacy and harm outcomes is strongly recommended }\end{array}$ \\
Participant timeline 13 & $\begin{array}{l}\text { Time schedule of enrolment, interventions (including any run-ins } \\
\text { and washouts), assessments, and visits for participants. A } \\
\text { schematic diagram is highly recommended (see Figure 1 \& 2) }\end{array}$ \\
Sample size & $14 \quad \begin{array}{l}\text { Estimated number of participants needed to achieve study } \\
\text { objectives and how it was determined, including clinical and } \\
\text { statistical assumptions supporting any sample size calculations }\end{array}$ \\
Recruitment & $15 \quad \begin{array}{l}\text { Strategies for achieving adequate participant enrolment to reach } \\
\text { target sample size }\end{array}$
\end{tabular}

\section{Methods: Assignment of interventions (for controlled trials)}

Allocation:

Sequence

generation

\begin{abstract}
Allocation concealment mechanism
\end{abstract}

Implementation
$16 a$ stratification. To reduce predictability of a random sequence, details of any planned restriction (eg, blocking) should be provided in a separate document that is unavailable to those who enrol participants or assign interventions

Mechanism of implementing the allocation sequence (eg, central telephone; sequentially numbered, opaque, sealed envelopes), describing any steps to conceal the sequence until interventions are assigned

Who will generate the allocation sequence, who will enrol participants, and who will assign participants to interventions
$6-7$

$6-7$ 


\begin{tabular}{llll}
\hline Section/item & $\begin{array}{l}\text { Item } \\
\text { No }\end{array}$ & Description & $\begin{array}{l}\text { Addressed on } \\
\text { page number }\end{array}$ \\
\hline
\end{tabular}

Who will be blinded after assignment to interventions (eg, trial Blinding (masking) 17a participants, care providers, outcome assessors, data analysts), and how

NA

If blinded, circumstances under which unblinding is permissible,

$17 \mathrm{~b}$ and procedure for revealing a participant's allocated intervention during the trial

\section{Methods: Data collection, management, and analysis}

Data collection methods

Data management

19

Statistical methods 20a $20 \mathrm{~b}$ Methods
analyses)

Definition of analysis population relating to protocol non-

20c adherence (eg, as randomised analysis), and any statistical methods to handle missing data (eg, multiple imputation) who discontinue or deviate from intervention protocols

Statistical methods for analysing primary and secondary analysis plan can be found, if not in the protocol
Plans for assessment and collection of outcome, baseline, and other trial data, including any related processes to promote data quality (eg, duplicate measurements, training of assessors) and a description of study instruments (eg, questionnaires, laboratory tests) along with their reliability and validity, if known. Reference to where data collection forms can be found, if not in the protocol

Plans to promote participant retention and complete follow-up, $18 \mathrm{~b}$ including list of any outcome data to be collected for participants

Plans for data entry, coding, security, and storage, including any related processes to promote data quality (eg, double data entry; range checks for data values). Reference to where details of data management procedures can be found, if not in the protocol outcomes. Reference to where other details of the statistical

13

NA NA 13 NA

\section{Methods: Monitoring}

Social Science Protocols, December 2019, 1-24. 


\begin{tabular}{|c|c|c|c|}
\hline Section/item & $\begin{array}{l}\text { Item } \\
\text { No }\end{array}$ & Description & $\begin{array}{l}\text { Addressed on } \\
\text { page number }\end{array}$ \\
\hline \multirow[t]{2}{*}{ Data monitoring } & $21 \mathrm{a}$ & $\begin{array}{l}\text { Composition of data monitoring committee (DMC); summary of } \\
\text { its role and reporting structure; statement of whether it is } \\
\text { independent from the sponsor and competing interests; and } \\
\text { reference to where further details about its charter can be found, if } \\
\text { not in the protocol. Alternatively, an explanation of why a DMC } \\
\text { is not needed }\end{array}$ & NA_ \\
\hline & $21 b$ & $\begin{array}{l}\text { Description of any interim analyses and stopping guidelines, } \\
\text { including who will have access to these interim results and make } \\
\text { the final decision to terminate the trial }\end{array}$ & NA_ \\
\hline Harms & 22 & $\begin{array}{l}\text { Plans for collecting, assessing, reporting, and managing solicited } \\
\text { and spontaneously reported adverse events and other unintended } \\
\text { effects of trial interventions or trial conduct }\end{array}$ & NA \\
\hline Auditing & 23 & $\begin{array}{l}\text { Frequency and procedures for auditing trial conduct, if any, and } \\
\text { whether the process will be independent from investigators and } \\
\text { the sponsor }\end{array}$ & NA_ \\
\hline \multicolumn{4}{|c|}{ Ethics and dissemination } \\
\hline $\begin{array}{l}\text { Research ethics } \\
\text { approval }\end{array}$ & 24 & $\begin{array}{l}\text { Plans for seeking research ethics committee/institutional review } \\
\text { board (REC/IRB) approval }\end{array}$ & 13 \\
\hline $\begin{array}{l}\text { Protocol } \\
\text { amendments }\end{array}$ & 25 & $\begin{array}{l}\text { Plans for communicating important protocol modifications (eg, } \\
\text { changes to eligibility criteria, outcomes, analyses) to relevant } \\
\text { parties (eg, investigators, REC/IRBs, trial participants, trial } \\
\text { registries, journals, regulators) }\end{array}$ & NA \\
\hline \multirow[t]{2}{*}{ Consent or assent } & $26 a$ & $\begin{array}{l}\text { Who will obtain informed consent or assent from potential trial } \\
\text { participants or authorised surrogates, and how (see Item 32) }\end{array}$ & -13 \\
\hline & $26 b$ & $\begin{array}{l}\text { Additional consent provisions for collection and use of participant } \\
\text { data and biological specimens in ancillary studies, if applicable }\end{array}$ & $\mathrm{NA}_{-}$ \\
\hline Confidentiality & 27 & $\begin{array}{l}\text { How personal information about potential and enrolled } \\
\text { participants will be collected, shared, and maintained in order to } \\
\text { protect confidentiality before, during, and after the trial }\end{array}$ & 13 \\
\hline
\end{tabular}

Social Science Protocols, December 2019, 1-24. 


\begin{tabular}{|c|c|c|c|}
\hline Section/item & $\begin{array}{l}\text { Item } \\
\text { No }\end{array}$ & Description & $\begin{array}{l}\text { Addressed on } \\
\text { page number }\end{array}$ \\
\hline $\begin{array}{l}\text { Declaration of } \\
\text { interests }\end{array}$ & 28 & $\begin{array}{l}\text { Financial and other competing interests for principal investigators } \\
\text { for the overall trial and each study site }\end{array}$ & 15 \\
\hline Access to data & 29 & $\begin{array}{l}\text { Statement of who will have access to the final trial dataset, and } \\
\text { disclosure of contractual agreements that limit such access for } \\
\text { investigators }\end{array}$ & 15 \\
\hline $\begin{array}{l}\text { Ancillary and post- } \\
\text { trial care }\end{array}$ & 30 & $\begin{array}{l}\text { Provisions, if any, for ancillary and post-trial care, and for } \\
\text { compensation to those who suffer harm from trial participation }\end{array}$ & NA \\
\hline \multirow[t]{3}{*}{$\begin{array}{l}\text { Dissemination } \\
\text { policy }\end{array}$} & $31 \mathrm{a}$ & $\begin{array}{l}\text { Plans for investigators and sponsor to communicate trial results to } \\
\text { participants, healthcare professionals, the public, and other } \\
\text { relevant groups (eg, via publication, reporting in results } \\
\text { databases, or other data sharing arrangements), including any } \\
\text { publication restrictions }\end{array}$ & \\
\hline & $31 b$ & $\begin{array}{l}\text { Authorship eligibility guidelines and any intended use of } \\
\text { professional writers }\end{array}$ & $\mathrm{NA}_{-}$ \\
\hline & $31 \mathrm{c}$ & $\begin{array}{l}\text { Plans, if any, for granting public access to the full protocol, } \\
\text { participant-level dataset, and statistical code }\end{array}$ & NA \\
\hline \multicolumn{4}{|l|}{ Appendices } \\
\hline $\begin{array}{l}\text { Informed consent } \\
\text { materials }\end{array}$ & 32 & $\begin{array}{l}\text { Model consent form and other related documentation given to } \\
\text { participants and authorised surrogates }\end{array}$ & NA \\
\hline $\begin{array}{l}\text { Biological } \\
\text { specimens }\end{array}$ & 33 & $\begin{array}{l}\text { Plans for collection, laboratory evaluation, and storage of } \\
\text { biological specimens for genetic or molecular analysis in the } \\
\text { current trial and for future use in ancillary studies, if applicable }\end{array}$ & NA \\
\hline
\end{tabular}

Social Science Protocols, December 2019, 1-24. 